\title{
The efficiency of systemic insecticides and complete fertilizer by trunk injection method against leopard moth in infested walnut trees
}

\author{
Alireza Mokhtaryan ${ }^{1}$, Aziz Sheikhigarjan ${ }^{2 *}$, Abbas Arbab ${ }^{1}$, Ali Mohammadipour ${ }^{2}$ and Hoda Ardestanirostami
}

\begin{abstract}
Background: Leopard moth, Zeuzera pyrina L., is a key pest of walnut trees in arid and dry areas. It severely damages walnut tree gardens with limitations on irrigation water in the growing season. This study was conducted to compare the efficacy of trunk injections of three systemic insecticides: imidacloprid, oxydemeton-methyl, thiamethoxam and a complete fertilizer, Nutreeno ${ }^{\circledR}$ against the leopard moth. Trunk injection was done by drilling. The walnut annual shoots of $60 \mathrm{~cm}$ in length were sampled from four directions of the treated and control trees in 4 months after treatments.
\end{abstract}

Results: The results showed that all treatments including the insecticides and the complete fertilizer at higher concentrations had acceptable efficacy on the leopard moth, and thiamethoxam was the best treatment.

Conclusions: Trunk injections by neonicotinoid insecticides and Nutreeno can be a safer control method against leopard moth larvae in old walnut trees around residential areas.

Keywords: Complete fertilizer, Imidacloprid, Systemic insecticide, Thiamethoxam

\section{Background}

Persian walnut (Juglans regia L.) is the second-most important nut crop grown in Iran. The number of walnut trees in that country is estimated to be more than 20 million, mostly seedlings, distributed on borders of farms and orchards or expanded in valleys. Total production of in-shell walnut is estimated at 400,000 t, and Iran is considered the third largest walnut producer in the world (Hassani et al., 2020).

Increasing walnut cultivation area in Iran and climate change over the last half century have caused walnut trees to be attacked by a large number of pests and diseases which have reduced the quality and quantity of

\footnotetext{
*Correspondence: asheikhi48@gmail.com

${ }^{2}$ Agricultural Research, Education and Extension Organization (AREEO),

Iranian Research Institute of Plant Protection, Tehran, Iran

Full list of author information is available at the end of the article
}

walnut production and destroyed walnut trees. Leopard moth, Zeuzera pyrina L. (Lepidoptera: Cossidae), is a major pest in arid and dry areas. The damage caused by this pest is severe in gardens with high restrictions on irrigation water in late spring and summer. So that the crop loss is $100 \%$ in unattended gardens. The pest attacks some host species of fruit trees (apples, pears, etc.) and non-fruit trees (maple, pussy, willow, elm and oak). Around 150 plant species have been reported to be hosts for leopard moth worldwide (Kolyaee \& Hasani, 2014).

Damage caused by leopard moth generally is observed in different parts of the tree's crown including shoots, main branches and the trunk of walnut trees. The pest can also damage fruits and saplings of walnut trees. The larval neonates often penetrate into the new shooting from the leaf connection to the stem and feed on woody tissue of the shoot. These larvae usually exit from young 
shoots during their growth and enter the thicker shoots. At the last larval instar, they enter the main shoots and the trunk and live there until the pupal stage and emerging of adult insects (Esmaili, 1983).

Following gardening principles including irrigation, nutrition and pruning is an important role in IPM of leopard moth along with mechanical controls such as using wires and injection of toxic paste into active pest holes and mass trapping by sex pheromones. Integration of these techniques has been an effective and conventional method against leopard moth in Iran (Esmaili, 1983). Mass trapping and mating disruption are the effective recommended control methods against leopard moth population (Hegazi et al., 2009; Hegazi et al., 2010; Patanita \& Vargas, 2007).

Insecticide application on old walnut trees is not more effective against leopard moth because the larvae are spending most of their lifetimes within the trunk, branches and shoots. Also adult emergence period of the leopard moths long last for 3-4 months (Hegazi et al., 2010).Timing is a key factor in the efficacy of chemical control against the leopard moth. Chemical treatments by foliage application and drenching at adult and egg stages can be effective (Sheikhi et al., 2016; Sheikhigarjan \& Kolyaee, 2013).

Loss caused by leopard moth is greater in older gardens with high crown walnut trees. In this kind of garden, foliage application of insecticides is very difficult and is not recommended. The trunk injection of systemic insecticides and complementary fertilizers can be an effective strategy in the management of the leopard moth. The aim of this study is the evaluation of the efficiency of three systemic insecticides and a complete fertilizer by trunk injection method in infested walnut trees.

\section{Methods}

\section{Test site}

The study was conducted in the walnut garden of Chubin Dar village at $36^{\circ} 13^{\prime} 42.6^{\prime \prime} \mathrm{N}$ and $49^{\circ} 56^{\prime} 42.2^{\prime \prime} \mathrm{E}$ in Eqbale-Gharbi rural district, in the central district of Qazvin county, Qazvin province, Iran. The walnut trees shared similar ages between 35 and 40-years-old, and the trunk diameter at breast height (DBH) was over $32 \pm 2 \mathrm{~cm}$.

\section{Insecticides and fertilizers}

In this trial, insecticides including Imidacloprid (Confidor $^{\circledR} 350$ SC, Bayer Crop Science, Germany), Oxydemeton-methyl (Metasystox $R^{\circledR} 100$ EC Bayer Crop Science, Germany) and Thiamethoxam (Actara ${ }^{\circledR} 250$ DF, Syngenta, EU) were diluted with water at different concentrations, and complete fertilizer (Nutreeno ${ }^{\circledR}$ L, Nutreeno, Malaysia) without diluting water were injected. All treatments were presented in Table 1.
Table 1 List of experimental treatments with three systemic insecticides and a complete fertilizer by optimal injection for infected walnut trees

\begin{tabular}{|c|c|c|c|}
\hline Treatments & $\begin{array}{l}\text { Trade name } \\
\text { (Formulation g/L) }\end{array}$ & $\begin{array}{l}\text { Formulation } \\
\text { rate } \\
\mathrm{ml} \text { or } \mathrm{g} / \text { tree }\end{array}$ & $\begin{array}{l}\text { Active } \\
\text { ingredient } \\
\text { g/tree }\end{array}$ \\
\hline Imidacloprid & Confidor $^{\circledR}$ (SC 350) & 10 & 3.5 \\
\hline Imidacloprid & Confidor $^{\circledR}$ (SC 350) & 20 & 7 \\
\hline Imidacloprid & Confidor $^{\circledR}$ (SC 350) & 5 & 1.75 \\
\hline Oxydemeton-methyl & $\begin{array}{l}\text { Metasystox } R^{\circledR}(E C \\
\text { 250) }\end{array}$ & 10 & 2.5 \\
\hline Oxydemeton-methyl & $\begin{array}{l}\text { Metasystox } R^{\circledR}(E C \\
\text { 250) }\end{array}$ & 20 & 5 \\
\hline Oxydemeton-methyl & $\begin{array}{l}\text { Metasystox } R^{\circledR}(E C \\
\text { 250) }\end{array}$ & 5 & 1.25 \\
\hline Complete fertilizer & Nutreeno ${ }^{\circledR} \mathrm{L}$ & 100 & 100 \\
\hline Complete fertilizer & Nutreeno ${ }^{\circledR} \mathrm{L}$ & 200 & 200 \\
\hline Thiamethoxam & Actara $^{\circledR}$ (DF 250) & 10 & 2.5 \\
\hline Thiamethoxam & Actara $^{\circledR}$ (DF 250) & 5 & 1.25 \\
\hline $\begin{array}{l}\text { Control (without } \\
\text { drilling) }\end{array}$ & 0 & 0 & 0 \\
\hline
\end{tabular}

The experiment was conducted in a completely randomized block design with 11 treatments and 3 replications. Each plot consisted of 4 walnut trees in the area. The tested trees were 35-years-old and fruitful. Trees of each treatment were marked with white color on the trunk.

\section{Trunk injection method}

For injection, a gasoline driller (made in Japan, model Eco with 18-mm-drill) was used. The holes were created at a height of $50 \mathrm{~cm}$ from the soil surface with a 45 degree angle to the outside of the trunk and down to the trunk of the tree. During drilling each tree, drill was washed in calcium hypochlorite solution $1 \%$ to prevent the incidence of viral and bacterial plant diseases. Trunk injection was performed in mid-spring and 2 weeks after the first emergence of leopard moth in sex pheromone traps and the onset of pest activity.

\section{Data collection and analysis}

A number of 10 annual shoots of $60 \mathrm{~cm}$ in length were selected from four directions of each tree, and the larval penetration holes (larvae of different ages) were counted in $60 \mathrm{~cm}$ length from top of the shoot. Samples were taken 3-4 months after the trunk injection. The percentage of efficiency in treatments was calculated by the method of Abbott as the following formula: 


$$
\text { Efficacy } \%=\left(\frac{C-T}{C}\right) \times 100
$$

In which: $C$ is the number of larval penetrations in control and $T$ is the number of larval penetrations in treatments. The number of larval penetrations and efficiency of the treatments were statistically analyzed using SAS version 9.2 (SAS Institute Inc. 2009). Mean number of holes and mean efficiency of treatments were compared by Duncan test at $5 \%$ level.

\section{Results}

The results in Table 2 showed that the trunk injection treatments were significant in the mean number of larval penetrations in annual shootings. Treatments including thiamethoxam (Actara $\left.{ }^{\circledR}\right) 2.5 \mathrm{~g}$ a.i./tree, complete fertilizer (Nutreeno ${ }^{\circledR}$ ) 200 and $100 \mathrm{ml} /$ tree and imidacloprid (Confidor $\left.{ }^{\circledR}\right) 7 \mathrm{~g}$ a.i./tree had the least mean number of leopard moth penetrations $2,3.5,3.25,5.5$ holes/10 shootings whereas check walnut trees had the most mean number of the penetrations ( 14 holes/10 shootings).Thiamethoxam $2.5 \mathrm{~g}$ a.i./tree had the best effectiveness, but no significant difference with above mentioned treatments. The efficacy of imidacloprid $20 \mathrm{ml} /$ tree $(76.78 \%)$ was higher than Imidacloprid 10 and $5 \mathrm{ml} /$ tree (60-67\%). In all treatments, the higher concentrations gave excellent reduction in larval damage of the leopard moth.

Table 2 The mean number of larval penetration holes in 10 green shootings of walnut trees in different injection treatments and their mean effectiveness

\begin{tabular}{|c|c|c|}
\hline $\begin{array}{l}\text { Treatments } \\
\text { g a.i./tree }\end{array}$ & $\begin{array}{l}\text { Mean number } \\
\text { of holes per } 10 \\
\text { shootings }\end{array}$ & Mean effectiveness (\%) \\
\hline Confidor $^{\circledR}(7)$ & $3.25 \pm 0.8 c^{*}$ & $76.78 \pm 6.09 a$ \\
\hline Confidor $^{\circledR}(3.5)$ & $5.5 \pm 2.5 b c$ & $60.71 \pm 18.09 a b$ \\
\hline Confidor $^{\circledR}(1.75)$ & $4.5 \pm 1.19 b c$ & $67.85 \pm 8.5 a$ \\
\hline Metasystox $R^{\circledR}(5)$ & $6 \pm 4.5 b c$ & $76.19 \pm 13.25 a$ \\
\hline Metasystox $R^{\circledR}(2.5)$ & $4.33 \pm 1.45 b c$ & $69.04 \pm 13.25 a$ \\
\hline Metasystox $\mathrm{R}^{\circledR}(1.25)$ & $10 \pm 2.67 a b$ & $39.64 \pm 13.11 b$ \\
\hline Nutreeno ${ }^{\circledR}(200)$ & $3.25 \pm 1.43 c$ & $76.78 \pm 10.22 \mathrm{a}$ \\
\hline Nutreeno ${ }^{\circledR}(100)$ & $3.5 \pm 0.9 c$ & $75 \pm 6.83 a$ \\
\hline Actara ${ }^{\circledR}(2.5)$ & $2 \pm 0.5 c$ & $85.71 \pm 4.12 \mathrm{a}$ \\
\hline Actara $^{\circledR}(1.25)$ & $4.4 \pm 0.67 b c$ & $68.57 \pm 4.84 a$ \\
\hline Control & $14 \pm 1.22 \mathrm{a}$ & - \\
\hline$d f_{\text {treatments, error }}$ & 10.31 & 9.28 \\
\hline$F$ & 3.28 & 1.6 \\
\hline $\operatorname{Pr}$ & 0.005 & 0.16 \\
\hline CV & 7 & 11.49 \\
\hline
\end{tabular}

*Treatments by the same letter (s) in the columns are not significantly different after analysis using the Duncan test at $5 \%$ level
Treatments of oxydemeton-methyl at two doses indicated that it could be effective on leopard moths, but at the low concentration of $1.25 \mathrm{~g}$ a.i./tree, it had the least efficacy among treatments. Using only complete fertilizer, Nutreeno ${ }^{\circledR}$ with two doses increased mortality of leopard moth larvae. Both of the doses had no significant difference in efficacy and number of holes/shooting. Their efficacies were the same as the best chemical insecticide, thiamethoxam.

\section{Discussion}

Increasing global warming and inappropriate distribution of rainfall due to climate change in the world have led to the leopard moth population outbreak in Iran and Middle East. The crop loss caused by this pest had significant economic impacts (Hegazi et al., 2015). The first step in the management of this pest is adhering to basic gardening principles and prevention methods. Chemical control by injection is a safe and low-risk control method along with other controls such as mating disruption and application of pesticide paste in the trunk holes in old walnut trees. The use of imidacloprid, thiamethoxam, oxydemeton-methyl insecticides by injection showed that this method could be an effective method against leopard moths in old walnut trees $10 \mathrm{~m}$ in height. The results also showed that the trunk injection of complete fertilizer could reduce the damage due to the leopard moth by increasing the inductive resistance of the tree. This control method makes the infested walnut trees to become stronger if they have grown in poor soils (Larson, 1994).

Systemic neonicotinoid insecticides have been used by trunk injection against borers, Agrilus planipennis Fairmaire in ash tree (Smitley et al., 2010), green date palm pit scale insect, Asterolecanium phoenicis Rao (Ahmed, 2006), some pests of forest trees and fruit trees (Aćimović et al., 2015; vanWoerkom et al., 2014; Wise et al., 2014). In this study, injection of imidacloprid and thiamethoxam against leopard moths had acceptable control in comparison with the results of mentioned studies. In green date palm, the effective injection dose of imidacloprid was $7 \mathrm{~g}$ a.i./palm against scale insect (Ahmed et al., 2013). In this study, dosage ranges of imidacloprid (0.13-0.56 g a.i./2.5 DBH) and thiamethoxam (0.1-0.2 g a.i./2.5 DBH) by injection usage were the close to the mentioned articles, $0.4 \mathrm{~g}$ a.i./2.5 DBH (Doccola et al., 2011; Smitley et al. 2010). All neonicotinoid treatments had acceptable efficacies. Due to the lack of access to the injection formulation of insecticides, the conventional formulations, Dry Flowable (DF) and Suspension Concentrate (SC) were used. These kinds of formulations leave sediments in the injection holes after injection and reduce the rate of pesticide uptake by the tree. Soluble Liquid (SL) formulation 
is more appropriate than other pesticide formulations (Berger \& Laurent, 2019; Rebek et al., 2012). The range of injection holes was reported to be of 2-9.5-mm-diameter in the trunk. In this study, injection holes of $9 \mathrm{~mm}$ in diameter were created by a drill method. The large holes not only can increase the infection risk of the tree to fungi and bacteria but also prolong the recovery period of injection holes in the tree. While it has been reported that in 4.6-mm-holes, the pesticide uptake rate was more than $3 \mathrm{~mm}$ holes (Zamora \& Escobar, 2000). And also insecticide distribution in the whole canopy of the tree by needle injection is more uniform in comparison with drill injection in the short term (Aćimović et al., 2016). When the trees are weak, the drill injection can increase the risk of disease infection and tree death in comparison with needle injection.

Injections of oxydemeton-methyl as an organic phosphorus insecticide into the tree trunk against elm leafbeetle, Galerucella luteola Mull (Saunders, 1971; Wene, 1970) on red gum lerp psyllid Glycaspis brimblecombei in eucalyptus trees (Young, 2002), citrus psylla in Iran (Motamedinia \& Morovati, 2012) and pear psylla ((Ardestanirostami et al., 2017) have been reported. They have shown acceptable results against the pest in first month after injection, but in the next months, the efficacy has declined. Our results showed that oxydemetonmethyl could affect well for a month and then it reduced over time. This is due to the instability of oxydemetonmethyl in walnut trees for long periods of time and the non-toxicity of its metabolites for leopard moth larvae. Investigations have reported that the half-life of Oxydemeton-methyl is 30-40 days (Lewis \& Tzilivakis, 2017).

The use of complete fertilizers can protect plants against biotic and abiotic factors (Fernández-Escobar, 2019). Injection of complete fertilizers and potassium diphosphate fertilizers can protect fruit and ornamental trees against pests such as the usage of Nutreeno fertilizer on pear psylla (Ardestanirostami et al., 2017), injection of phosphoric acid mixed with emamectin benzoate on apple scab and leafroller larvae, Choristoneura rosaceana (Coslor et al., 2019). In the management of Huanglongbing (HLB) or citrus greening in citrus, one of the strategies is the injection of antibiotics and activators to the trunk of the citrus (Hu et al., 2017). In the present study, both doses of Nutreeno have $75-76 \%$ efficacy and can be recommended at a dose of $100 \mathrm{ml} /$ tree to enhance and increase the resistance of walnut trees.

\section{Conclusions}

Leopard moth larvae cannot be active and cause damage to the trees that are in good conditions including irrigation, nutrition and maintenance. In these gardens, using mass trapping and mating disruption methods can reduce the damage up to zero (Hegazi et al., 2009, 2010), but in walnut trees with long interval irrigation, most strategies of IPM cannot effectively control leopard moths. To reinforce and recover the infested walnut trees with large canopy around residential areas, using insecticidal injections with a complete fertilizer, Nutreeno, for 2-3 years can reduce the damage due to leopard moth larvae. For developing insecticide injection method, we need to use water-soluble formulations and to study other systemic insecticides and then the interactional effects of the usage of a complete fertilizer with insecticides at the same time should be investigated in trunk injection.

\section{Abbreviation \\ DBH: Trunk diameter at breast height.}

\section{Acknowledgements}

We thank all members of plant protection department of Jihad-e Agriculture Organization of Qazvin Province for finding the infested walnut garden and marking the trees in this study. We also acknowledge Nasrin Khosravani for English review and revision.

\section{Authors' contributions}

Design of experiment, analysis and interpretation of data were conducted with contributions of AA and ASG. Trunk injection operation was done with ARM and AL. also ASG and AL had the main role in the identification of infested walnut trees. HA participated in English writing and also supported in sampling and evaluations. All authors have read and approved the manuscript", and ensure that this is the case.

\section{Funding}

This study was supported by Takestan Islamic Azad University, Qazvin, Iran and Iranian Research Institute of Plant Protection, Agricultural Research, Education and Extension Organization (AREEO).

\section{Availability of data and materials}

The datasets used and/or analyzed during the current study are available from the corresponding author on reasonable request.

\section{Declarations}

Ethics approval and consent to participate

Not applicable.

\section{Consent for publication}

Not applicable.

\section{Competing interests}

The authors declare that they have no competing interests.

\section{Author details}

'Department of Agricultural Entomology, Takestan Branch, Islamic Azad University, Takestan, Iran. ${ }^{2}$ Agricultural Research, Education and Extension Organization (AREEO), Iranian Research Institute of Plant Protection, Tehran, Iran.

Received: 20 June 2020 Accepted: 21 October 2021

Published online: 04 November 2021

\section{References}

Aćimović, S. G., Cregg, B. M., Sundin, G. W., \& Wise, J. C. (2016). Comparison of drill-and needle-based tree injection technologies in healing of trunk injection ports on apple trees. Urban Forestry \& Urban Greening., 19, $151-157$. 
Aćimović, S. G., Zeng, Q., McGhee, G. C., Sundin, G. W., \&Wise, J. C. (2015). Control of fire blight (Erwinia amylovora) on apple trees with trunk-injected plant resistance inducers and antibiotics and assessment of induction of pathogenesis-related protein genes. Frontiers in Plant Science, 6, 16.

Ahmed, M.A. (2006). The Efficacy of four systemic insecticides using two methods of application against the green date palm pit scale insect Asterolecanium phoenicis Rao (Palmapsis phoenicis)(Homoptera: Asterolecaniidae) in northern Sudan. In: III International date palm conference (vol. 736, pp. 369-389).

Ahmed, M. A., Abdelbagi, A. O., Elshafie, A. F. H., Fageer, E. A., \& Abass, I. A. (2013). Efficacy of imidacloprid (Confidor 200 SL) and improved cultural practices in the control of the green date palm pit scale insect (Asterolecanium phoenicis Rao) (Palmaspis phoenicis)(Homoptera: Asterolecaniidae) in Northern Sudan. Scientific Research and Essays, 8(37), 1752-1758.

Ardestanirostami, H., Sheikhigarjan, A., Arbab, A., \& Javadzadeh, M. (2017). Control of pear psylla, Cacopsylla pyricola by trunk injection of azadirachtin and complete fertilizer. Iranian Journal of Plant Protection Science., 47(2), 253-261.

Berger, C., \& Laurent, F. (2019). Trunk injection of plant protection products to protect trees from pests and diseases. Crop Protection. https://doi.org/10. 1016/j.cropro.2019.05.025

Coslor, C. C., Sundin, G. W., \&Wise, J. C. (2019). The efficacy of trunk injections of emamectin benzoate and phosphorous acid for control of obliquebanded leafroller andapple scab on semi-dwarf apple. Crop Protection, 118, 44-49.

Doccola, J.J., Smitley, D.R., Davis, T.W., Aiken, J.J., \& Wild, P.M. (2011). Tree wound responses following systemic insecticide trunk injection treatments in green ash (Fraxinus pennsylvanica Marsh.) as determined by destructive autopsy. Arboriculture and Urban Forestry 37: 6-12.

Esmaili, M. (1983). Important pests of fruit trees. Sepehr Publisher.

Fernández-Escobar, R. (2019). Olive nutrition and tolerance to abiotic and biotic stresses. Frontiers in Plant Science, 10, 1-7.

Hassani, D., Mozaffari, M. R., Soleimani, A., Dastjerdi, R., Rezaee, R., Keshavarzi, M., Vahdati, K., Fahadan, A., \& Atefi, J. (2020). Four new Persian walnut cultivars of Iran: Persia, Caspian, Chaldoran, and Alvand. HortScience, 55(7), 1162-1163.

Hegazi, E., Khafagi, W. E., Konstantopoulou, M., Raptopoulos, D., Tawfik, H., El-Aziz, G. A., El-Rahman, S. A., Atwa, A., Aggamy, E., \& Showeil, S. (2009). Efficient mass-trapping method as an alternative tactic for suppressing populations of leopard moth (Lepidoptera: Cossidae). Annals of the Entomological Society of America, 102(5), 809-818.

Hegazi, E. M., Khafagi, W. E., Konstantopoulou, M. A., Schlyter, F., Raptopoulos, D., Shweil, S., Abd El-Rahman, S., Atwa, A., Ali, S. E., \& Tawfik, H. (2010). Suppression of leopard moth (Lepidoptera: Cossidae) populations in olive trees in Egypt through mating disruption. Journal of Economic Entomology, 103(5), 1621-1627.

Hegazi, E., Schlyter, F., Khafagi, W., Atwa, A., Agamy, E., \& Konstantopoulou, M. (2015). Population dynamics and economic losses caused by Zeuzera pyrina, a cryptic wood-borer moth, in an olive orchard in Egypt. Agricultural and Forest Entomology, 17(1), 9-19.

Hu, J., Jiang, J., \& Wang, N. (2017). Control of citrus huanglongbing via trunk injection of plant defense activators and antibiotics. Phytopathology, 108, 186-195.

SAS Institute. (2009). What's new in SASVR 9.2. SAS Institute Inc., Cary, NC.

Kolyaee, R., \& Hasani, D. (2014). Possibility of leopard moth control in walnut orchards through male mass trapping technique, using sex pheromone. Research Achievements for Field and Horticulture Crops., 3(1), 27-37.
Larson, D. W., Doubt, J., \& Matthes-sears, U. (1994). Radially sectored hydraulic pathways in the xylem of Thuja occidentalis as revealed by the use of dyes. International Journal of Plant Sciences, 155, 569-582.

Lewis, K., \& Tzilivakis, J. (2017). Development of a data set of pesticide dissipation rates in/on various plant matrices for the Pesticide Properties Data Base (PPDB). Data, 2(3), 28. https://doi.org/10.3390/data2030028

Motamedinia, B., \& Morovati, M. (2012). Study on spraying and injection of chemical compounds and commercial neem extract on Asian citrus psyllid, Diaphorina citri Kuwayama (Hemiptera: Psyllidae) in Baluchestan. Plant Pest Research., 2(1), 13-19.

Patanita M.I., \&Vargas, E. (2007). Preliminary results in Zeuzera pyrina control with mass trapping method in Alentejo (Portugal). In: 59th International symposium on crop protection, Gent Belgium. [Advance online publication.]. Retrieved June 25, 2009, from http://www.actahort.org/books/686/ 68658.htm.

Rebek, E. J., Frank, S. D., Royer, T. A., \& Bográn, C. E. (2012). Alternatives to chemical control of insect pests. Insecticides - Basic and other applications (pp. 171-196). Shanghai: Intech.

Saunders, J. L. (1971). Trunk drenches and injections for elm leaf beetle control. Journal of Economic Entomology., 64(5), 1287-1288.

Sheikhigarjan, A., and Kolyaee, R. (2013). Efficacy of spot spray against Leopard moth Zeuzera pyrina L. (Lep.: Cossidae). Final Report, Iranian Research institute plant protection (IRIPP), Agricultural Research, Education and Extension Organization (AREEO), Report No. 51217, Tehran, Iran.

Sheikhi, A., Arbabtafti, R., Kolyaee, R., \& Mohammadipour, A. (2016). Efficacy of imidacloprid insectigation against leopard moth Zeuzera pyrina L. (Lep.: Cossidae) on walnut trees. Journal of Plant Protection, 39(2), 37-45.

Smitley, D. R., Doccola, J. J., \& Cox, D. L. (2010). Multiple-year protection of ash trees from emerald ash borer with a single trunk injection of emamectin benzoate, and single-year protection with an imidacloprid basal drench. Journal of Arboriculture, 36(5), 206-211.

vanWoerkom, A. H., Aćimović, S. G., Sundin, G. W., Cregg, B. M., Mota-Sanchez, D., Vandervoort, C., \&Wise, J. C. (2014). Trunk injection: An alternative technique for pesticide delivery in apples. Crop Protection, 65, 173-185.

Wene, G. P. (1970). Evaluation of systemic drenches and trunk injections as controls for the elm leaf beetle in Arizona. Journal of Economic Entomology, 63(4), 1326-1328.

Wise, J. C., vanWoerkom, A. H., Acimovic, S. G., Sundin, G. W., Cregg, B. M., \& Vandervoort, C. (2014). Trunk injection: A discriminating delivering system for horticulture crop IPM. Entomology, Ornithology \& Herpetology, 3(2), 1-7.

Young, L. C. (2002). The efficacy of micro-injected imidacloprid and oxydemeton-methyl on red gum eucalyptus trees (Eucalyptus camaldulensis) infested with red gum lerp psyllid (Glycaspis brimblecombei). Journal of Arboriculture, 28, 144-147.

Zamora, M. S., \& Escobar, R. F. (2000). Injector-size and the time of application affects uptake of tree trunk-injected solutions. Scientia Horticulturae, 84(1-2), 163-177.

\section{Publisher's Note}

Springer Nature remains neutral with regard to jurisdictional claims in published maps and institutional affiliations.

\section{Submit your manuscript to a SpringerOpen ${ }^{\odot}$ journal and benefit from:}

- Convenient online submission

- Rigorous peer review

- Open access: articles freely available online

- High visibility within the field

- Retaining the copyright to your article

Submit your next manuscript at springeropen.com 